\title{
THE INFLUENCE OF TAILINGS AND CEMENT TYPE ON DURABILITY PROPERTIES OF SELF-COMPACTING CONCRETE
}

\author{
Ksenija Janković, Nenad Šušić, Marko Stojanović, Dragan Bojović, Ljiljana Lončar
}

Preliminary communication

In order to examine the differences in chemical composition and the possibility of using mine tailings in mortar and concrete production, samples were taken from the landfill and directly from the production. Tailings test results showed no pozzolanic activity and that its application in concrete can be only a partial replacement of aggregate. This paper presents the possibility of using tailings in self-compacting concrete made with Portland cement and sulphate resistant cement. Concrete specimens in which the aggregate fraction $0 / 4 \mathrm{~mm}$ was replaced with 10 and $20 \%$ of tailings were examined. The resistance to freezing and thawing with and without de-icing salts is used as an indicator of concrete durability.

Keywords: CEM I; CEM III; durability; self-compacting concrete; tailings

Utjecaj jalovine i vrste cementa na trajnost samougrađujućeg betona

Prethodno priopćenje

Da bi se ispitala razlika u kemijskom sastavu i mogućnost primjene jalovine iz rudnika u proizvodnji žbuke i betona uzeti su uzorci s deponija i direktno iz proizvodnje. Nijedan uzorak nije pokazao pucolansku aktivnost. Iz tog razloga, ovaj materijal je moguće koristiti samo kao dkelimičnu zamenu za agregat. U ovom radu je prikazana mogućnost uporabe jalovina u samougrađujućem betonu pripremljenim s portland cementom i sulfatno otpornim cementom. Ispitivani su betonski uzorci u kojima je frakcija agregata $0 / 4 \mathrm{~mm}$ zamijenjena s 10 i $20 \%$ jalovine. Kao pokazatelj trajnosti betona uzete su otpornosti prema zamrzavanju i odmrzavanju sa i bez soli za odmrzavanje.

Ključne reči: CEM I; CEM III; jalovina; samougrađujući beton; trajnost

\section{Introduction}

During the ore flotation in the mine, and technogenic raw material slag from furnace, large amounts of flotation tailings are generated and as a waste material it is disposed in the specially determined areas in the industrial site. With the increase in metal production, the amount of tailings also increases, which is a major environmental problem because it takes up large areas. Concrete, as the most commonly used construction material in the world, requires the development and implementation of new technologies that are based on sand, flotation tailings etc.

Thomas et al. investigates the possibility of using copper tailing in cement concrete as a partial replacement of natural river sand [1]. The copper tailing concrete (up to $60 \%$ substitution) exhibited good strength and durability characteristics.

Onuaguluchi and Eren [2] investigated effect of the application of copper tailings which substitute $0 \%, 5 \%$ and $10 \%$ of cement mass on the properties of fresh and hardened mortar. Copper tailings blended mortars showed higher strength and abrasion resistance.

Choi et al. [3] presents the feasibility of incorporating tailings from tungsten mine waste (TTMW) and ground granulated blast-furnace slag (GBFS) in the development of mortar with acceptable properties. The study showed that increasing the TTMW content in mortar mixes decreased both flowability and compressive strength. The authors suggest that mortar with acceptable properties can be developed using moderate volumes of TTMW (up to $10 \%$ by mass).

The aim of paper by González-Corrochano et al. [4] was to study the combined effects of prefiring and firing dwell times on the chemical, physical and microstructural properties of artificial lightweight aggregates produced from mining and industrial waste, including polluted mine soil and coal combustion products. The same authors present a study about the effectiveness of thermal treatment in the immobilization of different chemical elements within the structure of artificial lightweight aggregates (LWAs) manufactured with contaminated mine soil and fly ash [5].

Argane et al. research the use of low sulfide or sulfide free tailings (LST) as aggregates for rendering mortars, focusing on their cement hydration and durability. Experimental results confirmed that LST-based renders seem to involve different cement hydration processes, which lead to larger pore size distribution and lower CSH and portlandite content. These observations significantly influence their susceptibility to cracking and sulfate attack resistance [6].

The same authors present an experimental program using mechanical tests, mineralogical investigations and leaching tests presented to assess the use of low sulfide base metal tailings, with varying properties, as fine aggregates for rendering and masonry mortars. The $\mathrm{Pb}-\mathrm{Zn}$ fraction, when using the appropriate substitution level, may serve as an active set retardant improving mortars setting time. The leaching of metals was also successfully stabilized in mortars [7].

The objectives of the research are as follows:

- Testing of the physico-mechanical and chemical properties of the tailings and determining its application in self-compacting concrete (SCC)

- Variation of the percentage of tailings in the SCC and its impact on the SCC workability

- The possibility of using tailings in self-compacting concrete made with Portland cement (CEM I) and sulphate resistant cement (CEM III)

- Testing of the mechanical properties of SCC and the resistance to freezing and thawing with and without de-icing salts. 


\section{Experimental work}

\subsection{Component materials}

Self-compacting concrete was prepared with two types of cement CEM I and CEM III. Chemical properties of both types of cement are shown in Tab. 1.

Table 1 Chemical composition of cement (\%)
\begin{tabular}{|c|c|c|}
\hline Oxide & $\begin{array}{c}\text { Cement } \\
\text { CEM I 42.5R }\end{array}$ & $\begin{array}{c}\text { Cement } \\
\text { CEM III/B 32.5N } \\
\text { LH/SR }\end{array}$ \\
\hline $\mathrm{SiO}_{2}$ & 20,59 & 31,82 \\
\hline $\mathrm{Al}_{2} \mathrm{O}_{3}$ & 6,10 & 7,36 \\
\hline $\mathrm{Fe}_{2} \mathrm{O}_{3}$ & 2,81 & 1,32 \\
\hline $\mathrm{CaO}$ & 63,44 & 44,21 \\
\hline $\mathrm{MgO}$ & 1,89 & 7,88 \\
\hline $\mathrm{Na}_{2} \mathrm{O}$ & 0,29 & 0,40 \\
\hline $\mathrm{SO}_{3}$ & 2,69 & 2,92 \\
\hline $\mathrm{CI}^{-}$ & 0,003 & 0,014 \\
\hline $\mathrm{S}^{2-}$ & - & 0,42 \\
\hline $\mathrm{K}_{2} \mathrm{O}$ & - & 0,57 \\
\hline $\mathrm{MnO}$ & - & 0,736 \\
\hline Loss on ignition & 2,187 & 2,35 \\
\hline
\end{tabular}

Natural, separated aggregate from river Morava with $0 / 4,4 / 8,8 / 16 \mathrm{~mm}$ fractions was used. The percentage share of aggregate: $0 / 4 \mathrm{~mm}-45 \%, 4 / 8 \mathrm{~mm}-25 \%$ and $8 / 16 \mathrm{~mm}-30 \%$. Diagram of aggregate mixtures is shown in Fig. 1.

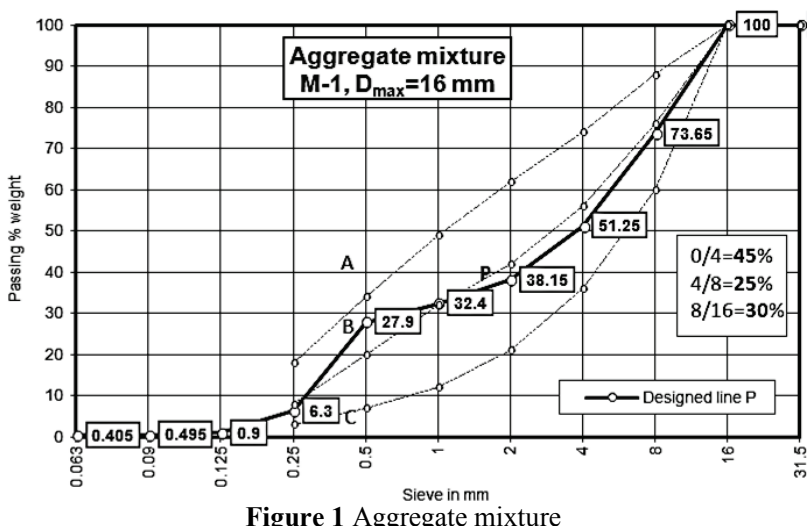

A mineral additive Type I - limestone was used. The particle size of the mineral additive is less than $100 \mu \mathrm{m}$. It has no pozzolanic properties, and it was used as filler (for SCC a large amount of fine particles is necessary).

Two kinds of adsmixtures were applied: super plasticizer and the air entraining admixture.

For the purpose of this study two samples of mine tailings were taken from the $\mathrm{Pb}$ and $\mathrm{Zn}$ mines, one from the tailings dump (01) and the other directly from the production process (02). Complete testing of chemical, physical, and mechanical properties of the samples was performed. The chemical composition of the tailings samples was determined by chemical analysis according to SRPS EN 196-2 standard. There active $\mathrm{SiO}_{2}$ and $\mathrm{CaO}$ content was calculated on the basis of the results of chemical analysis according to SRPS EN 197-1 standard. The test results are shown in Tab. 2. A sample of mine tailing from a landfill is presented in Fig. 2.

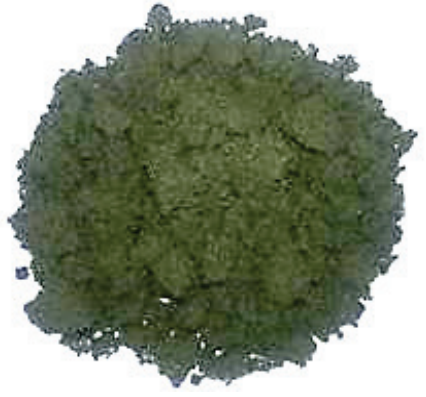

Figure 2 Mine tailing from a landfill

Table 2 The chemical properties of tailings

\begin{tabular}{|c|c|c|}
\hline & 01 & 02 \\
\hline Loss on ignition at $950{ }^{\circ} \mathrm{C}, \%$ & 5,61 & 4,25 \\
\hline $\mathrm{SiO}_{2}, \%$ & 43,26 & 41,62 \\
\hline $\mathrm{Al}_{2} \mathrm{O}_{3}, \%$ & 11,11 & 11,19 \\
\hline $\mathrm{Fe}_{2} \mathrm{O}_{3}, \%$ & 15,57 & 14,51 \\
\hline $\mathrm{CaO}, \%$ & 20,01 & 19,67 \\
\hline $\mathrm{MgO}, \%$ & 4,31 & 3,71 \\
\hline $\mathrm{SO}_{3}, \%$ & 0,32 & 0,15 \\
\hline $\mathrm{Na}_{2} \mathrm{O}, \%$ & 0,92 & 1,14 \\
\hline $\mathrm{K}_{2} \mathrm{O}, \%$ & 1,00 & 1,42 \\
\hline $\mathrm{CO}_{2}, \%$ & 4,42 & 3,02 \\
\hline Insoluble residue in $\mathrm{HCl} / \mathrm{Na}_{2} \mathrm{CO}_{3}, \%$ & 66,37 & 63,25 \\
\hline Insoluble residue in $\mathrm{HCl} / \mathrm{KOH}, \%$ & 46,15 & 51,60 \\
\hline content reactive silicon dioxide $\mathrm{SiO}_{2}, \%$ & 16,04 & 11,20 \\
\hline content reactive calcium oxideCaO, \% & 14,15 & 15,72 \\
\hline
\end{tabular}

The physical properties of the tailings were determined in accordance with SRPS B.C1.018 standard. The samples were milled because of a high content of coarse particles (Fig. 3) so that the residue on the 0,063 mm sieve was up to $10 \%$, and then tested for pozzolanic activity using lime. Pozzolanic activity of the tailings was determined as the strength of mortar samples prepared from $300 \mathrm{~g}$ of milled tailings sample, $1350 \mathrm{~g}$ of quartz sand, $150 \mathrm{~g}$ of hydrated lime, and $270 \mathrm{~g}$ of water.

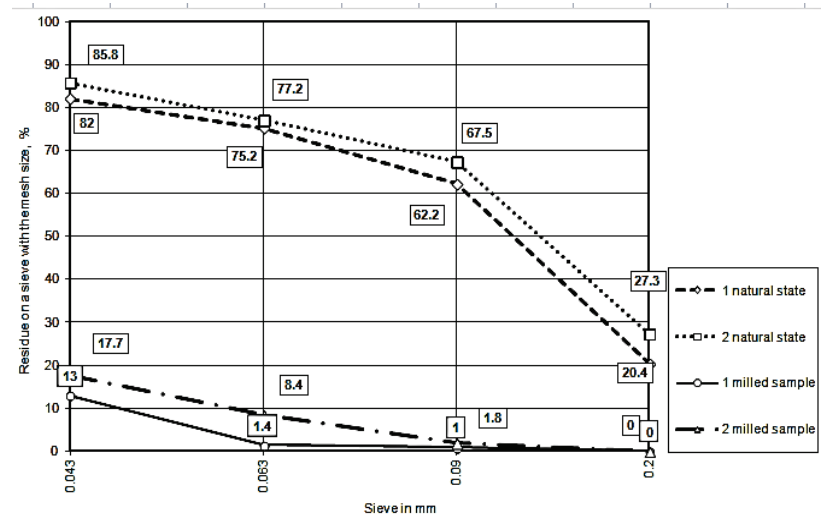

Figure 3 Aggregate size distribution

The flexural and compressive strength were tested after the samples were cured for 24 hours at $20{ }^{\circ} \mathrm{C}$ and at a relative humidity of more than $90 \%$, and then 7 days at $55{ }^{\circ} \mathrm{C}$ and at a relative humidity of more than $90 \%$.

The results of pozzolanic activity were extremely low (flexural strength $0,0 \mathrm{MPa}$, compressive strength 0,4 $\mathrm{MPa}$ ), which confirmed the results of the reactive $\mathrm{SiO}_{2}$ content calculation. The conclusion is that this material is not suitable for cement replacement in concrete and mortar or as a pozzolanic cement additive. Further investigations were focused on the possibility of using 
tailings as a substitute of a part of aggregate in the preparation of mortar and concrete. Tailings samples can only be used for replacement of a part of the fine aggregate (Fig. 3).

\subsection{Mortar}

Standard cement mortar and mortars in which a part of aggregates was replaced with tailings were prepared for the testing described in this paper. The following materials were used for the preparation of standard cement mortar:

- Portland cement CEM I 42.5 R Lafarge BFC

- Aggregate-fraction 0-4 mm (natural river sand)

- Water

in the ratio of $1: 3: 0.5$.

This mortar was used as the referent (E) for comparison of the physical- mechanical testing performed on mortars in which tailings substituted a portion of the aggregate. Four mortar mixtures in which the percentage of tailings in the aggregates mixture was $5 \%$ and $10 \%$, two of which were with tailings taken from a landfill (01) and two with tailings taken directly from the production process (02) were made. Flexural and compressive strength of the samples after 28 days in accordance with the SPRS EN 1015-21 are shown in Fig. 4.

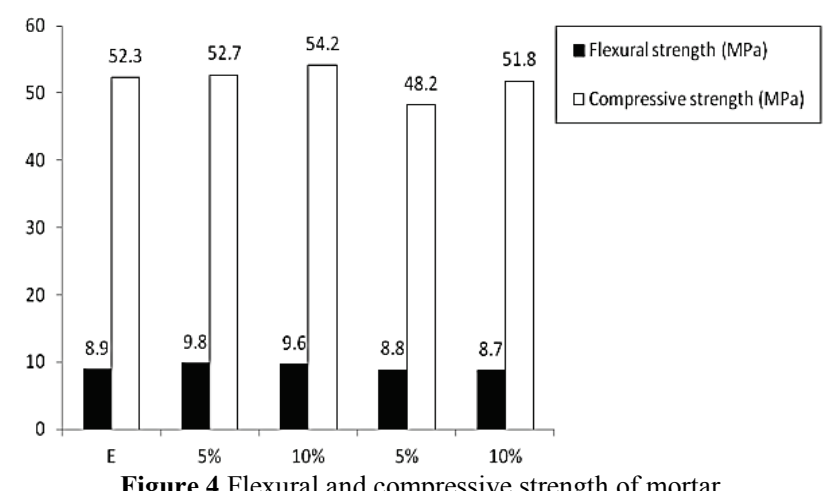

\subsection{Self-compacting concrete}

For the tests described in this paper self-compacting concretes with a part of the aggregate replaced with tailings from a landfill ((1) from Tab. 2) were made. For the preparation of self-compacting concrete the following materials were used:

- Two types of cement:

- Cement Tip I: CEM I 42.5 R, Lafarge BFC

- Cement Tip II: CEM III/B 32,5N LH/SR, Lafarge BFC

- Aggregate: river, washed and separated into fractions $0 / 4,4 / 8,8 / 16 \mathrm{~mm}$

- $\quad$ Mineral additive Type I: filler

- Mine tailing from landfill

- Chemical admixture: Superplasticizer (polycarboxylate)

- Chemical admixture: Air entraining

- Water: potable water.

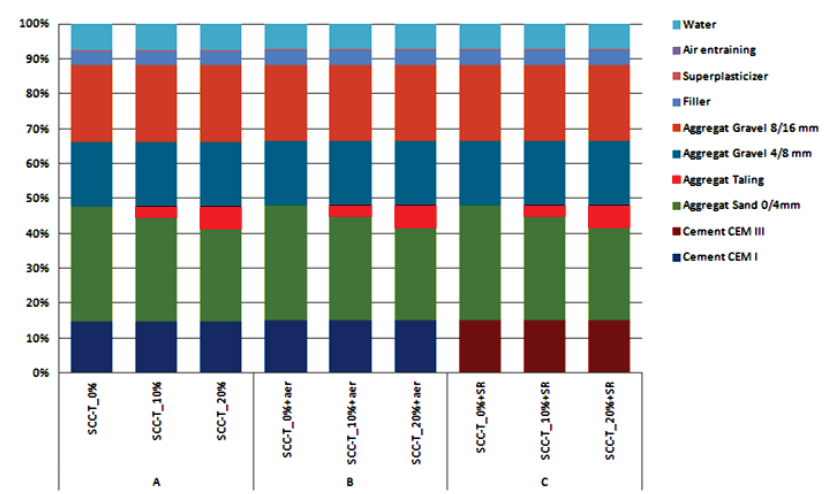

Figure 5 Concrete components expressed in percentage

Composition of concrete mixtures is shown in Fig. 5 and Tab. 3. Self-compacting concrete is split into three types:

A - SCC-T_\% - SCC concrete made with Portland cement CEM I $\overline{42} .5 \mathrm{R}$ and a partial replacement of 10 and $20 \%$ of fine aggregate with tailings

B - SCC-T \%+aer - SCC concrete made with Portland cement $\overline{\mathrm{C}} \mathrm{EM}$ I $42.5 \mathrm{R}$ and a partial replacement of 10 and $20 \%$ of fine aggregate with tailings with airentraining admixture

C - SCC-T_\%+SR - SCC concrete made with sulphate-resistant cement CEM III/B 32,5 N LH/SR and a partial replacement of 10 and $20 \%$ of fine aggregate with tailings with air-entraining admixture.

Table 3 Composition of concrete mixtures

\begin{tabular}{|c|c|c|c|c|c|c|c|c|c|c|c|}
\hline & \multirow{3}{*}{ Mix number } & \multicolumn{2}{|c|}{ Cement } & \multicolumn{3}{|c|}{ Aggregat } & \multirow[b]{2}{*}{ Filler } & \multirow[b]{2}{*}{ Taling } & \multirow[b]{2}{*}{ Superplasticizer } & \multirow{2}{*}{$\begin{array}{c}\text { Air } \\
\text { etraining } \\
\text { admixture }\end{array}$} & \multirow[b]{2}{*}{ Water } \\
\hline & & CEM I & CEM III & $\begin{array}{c}\text { Sand } \\
0 / 4 \mathrm{~mm}\end{array}$ & $\begin{array}{l}\text { Gravel } \\
4 / 8 \mathrm{~mm}\end{array}$ & $\begin{array}{c}\text { Gravel } \\
8 / 16 \mathrm{~mm}\end{array}$ & & & & & \\
\hline & & $\mathrm{kg} / \mathrm{m}^{3}$ & $\mathrm{~kg} / \mathrm{m}^{3}$ & $\mathrm{~kg} / \mathrm{m}^{3}$ & $\mathrm{~kg} / \mathrm{m}^{3}$ & $\mathrm{~kg} / \mathrm{m}^{3}$ & $\mathrm{~kg} / \mathrm{m}^{3}$ & $\mathrm{~kg} / \mathrm{m}^{3}$ & $\mathrm{~kg} / \mathrm{m}^{3}$ & $\mathrm{~kg} / \mathrm{m}^{3}$ & $\mathrm{~kg} / \mathrm{m}^{3}$ \\
\hline \multirow{3}{*}{ A } & SCC-T $0 \%$ & 350 & 0 & 782 & 434 & 521 & 100 & 0 & 3.6 & 0 & 180 \\
\hline & SCC-T $10 \%$ & 350 & 0 & 703.8 & 434 & 521 & 100 & 78.2 & 3.6 & 0 & 180 \\
\hline & SCC-T 20\% & 350 & 0 & 625.6 & 434 & 521 & 100 & 156.4 & 3.6 & 0 & 180 \\
\hline \multirow{3}{*}{ B } & SCC-T $0 \%+$ aer & 350 & 0 & 758 & 421 & 505 & 100 & 0 & 3.5 & 0.046 & 170 \\
\hline & SCC-T $10 \%+$ aer & 350 & 0 & 682.2 & 421 & 505 & 100 & 75.8 & 3.5 & 0.046 & 170 \\
\hline & SCC-T $20 \%+$ aer & 350 & 0 & 606.4 & 421 & 505 & 100 & 151.6 & 3.5 & 0.046 & 170 \\
\hline \multirow{3}{*}{$\mathrm{C}$} & SCC-T_0\%+SR & 0 & 350 & 752 & 418 & 501 & 100 & 0 & 3.5 & 0.046 & 180 \\
\hline & SCC-T_10\%+SR & 0 & 350 & 676.8 & 418 & 501 & 100 & 75.2 & 3.5 & 0.046 & 180 \\
\hline & SCC-T_20\%+SR & 0 & 350 & 601.6 & 418 & 501 & 100 & 150.4 & 3.5 & 0.046 & 180 \\
\hline
\end{tabular}

Fresh concrete is designed to meet the minimum properties of self-compacting concrete, according to SRPS EN 209-1 standard [8]. For all types, a referent mixture and two mixtures in which a part of the fine aggregate (10 or $20 \%$ ) was replaced with tailings were prepared. 


\subsubsection{Properies of fresh concrete}

By testing the properties of fresh SCC concrete it should be demonstrated what impact the replacement of fine fractions of aggregate has on the rheological properties of fresh SCC concrete. The following properties of SCC concrete were tested: slump flow, testing with V-funnel and L-box according to SRPS EN
12350-8, SRPS EN 12350-9 and SRPS EN 12350-10 standards.

The properties of self-compacting concrete with and without tailings are shown in Tab. 4. Bulk density of fresh concrete was tested according to SRPS EN 12350-6 standard and ranged from 2300 to $2370 \mathrm{~kg} / \mathrm{m}^{3}$. In addition to this testing, the testing of entrained air in fresh concrete was performed according to SRPS EN 12350-7 standard.

Table 4 The properties of self-compacting concrete with and without tailings

\begin{tabular}{|c|l|c|c|c|c|}
\hline \multirow{3}{*}{$\begin{array}{c}\text { Type } \\
\text { Concrete }\end{array}$} & Mix number & $\begin{array}{c}\text { Slump flow } \\
\text { SRPS EN 12350-8 }\end{array}$ & $\begin{array}{c}\text { V funnel } \\
\text { SRPS EN 12350-9 }\end{array}$ & $\begin{array}{c}\text { L-box (3 bars) } \\
\text { SRPS EN 12350-10 }\end{array}$ & $\begin{array}{c}\text { Entrained air } \\
\text { SRPS EN 12350-7 }\end{array}$ \\
\cline { 3 - 6 } & & $(\mathrm{mm})$ & $(\mathrm{sec})$ & PL=H2/H1 & $\%$ \\
\hline \multirow{3}{*}{ A } & 610 & 6,7 & 0,84 & 2,7 \\
& SCC-T_0\% & 600 & 7,1 & 0,91 & 0,8 \\
\cline { 2 - 6 } & SCC-T_10\% & 600 & 7,6 & 0,96 & 1,7 \\
\cline { 2 - 6 } & SCC-T_20\% & 640 & 7,5 & 0,96 & 3,4 \\
\hline \multirow{3}{*}{ B } & SCC-T_0\%+aer & 690 & 7,8 & 0,84 & 3,5 \\
\cline { 2 - 6 } & SCC-T_10\%+aer & 650 & 7,9 & 1,10 & 3,9 \\
\cline { 2 - 6 } & SCC-T_20\%+aer & 700 & 7,8 & 1,00 & 4,2 \\
\hline \multirow{2}{*}{ C } & SCC-T_0\%+SR & 690 & 7,9 & 0,82 & 3,3 \\
\cline { 2 - 6 } & SCC-T_10\%+SR & 650 & 8,2 & & 5,1 \\
\cline { 2 - 6 } & SCC-T_20\%+SR & & & & \\
\hline
\end{tabular}

\subsubsection{Compressive strength}

Samples for testing compressive strength of concrete were made. Concrete was compacted without vibration in metal cube-shaped molds with an edge length of $d=100$ $\mathrm{mm}$, and the samples were cured in water at a temperature of $+20{ }^{\circ} \mathrm{C}$ until they were tested according to SRPS EN 12390-2 standard.
Testing compressive strength of concrete at the age of 3, 7, 28 and 56 days was carried out according to SRPS EN 12390-3 standard. Bulk density of hardened concrete was tested according to SRPS EN 12390-7 standard and ranged from 2280 to $2350 \mathrm{~kg} / \mathrm{m}^{3}$. The test results are shown in Tab. 5.

Table 5 Compressive strength of self-compacting concrete with mine tailing

\begin{tabular}{|c|c|c|c|c|c|}
\hline \multirow{2}{*}{$\begin{array}{c}\text { Type } \\
\text { Concrete }\end{array}$} & \multirow{2}{*}{ Mix number } & \multicolumn{4}{|c|}{ Compressive strength $\left(\mathrm{N} / \mathrm{mm}^{2}\right)$} \\
\hline & & 3 days & 7 days & 28 days & 56 days \\
\hline \multirow{3}{*}{ A } & SCC-T_0\% & 43,3 & 52,9 & 62,5 & - \\
\hline & SCC-T_10\% & 47,8 & 53,0 & 66,7 & - \\
\hline & SCC-T_20\% & 42,8 & 52,5 & 65,7 & - \\
\hline \multirow{3}{*}{ B } & SCC-T_0\%+aer & 42,7 & 50,5 & 56,6 & - \\
\hline & SCC-T_10\%+aer & 40,1 & 47,9 & 56,7 & - \\
\hline & SCC-T_20\%+aer & 43,8 & 52,0 & 58,4 & - \\
\hline \multirow{3}{*}{$\mathrm{C}$} & SCC-T_0\%+SR & 12,6 & 22,0 & 42,8 & 50,6 \\
\hline & SCC-T_10\%+SR & 9,4 & 23,7 & 44,8 & 53,3 \\
\hline & SCC-T_20\%+SR & 14,4 & 29,0 & 49,2 & 51,5 \\
\hline
\end{tabular}

\subsubsection{Freeze / thaw resistance with de-icing salts}

Concrete resistance to frost and de-icing salts is determined by the degree of damage to the concrete surface of the sample after 25 cycles of freezing and thawing. The surface is covered with a $3 \% \mathrm{NaCl}$ solution. The samples are exposed to temperature of $-20{ }^{\circ} \mathrm{C}$ for 16 to 18 hours and then at temperature of $20{ }^{\circ} \mathrm{C}$ for 6 to 8 hours, according to SRPS U.M1.055. Test results are shown in Fig. 6.

Concrete surfaces which are exposed to frost and deicing salts showed that concrete without air entraining admixture and concrete with sulphate resistant cement without mine tailings have achieved the $2^{\text {nd }}$ level of damage, that is, the surfaces of these concrete are not resistant to frost and de-icing salts. The surfaces of all other concrete are resistant to freezing and thawing with de-icing salts.

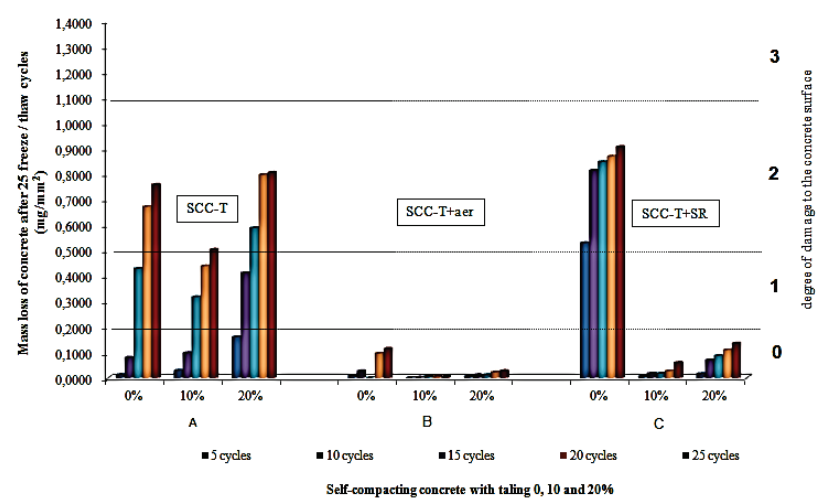

Figure 6 Mass loss of concrete after 25 freeze / thaw cycles 


\subsubsection{Freeze / thaw resistance}

The samples, cubes $(d=100 \mathrm{~mm})$ were made in laboratory conditions, and were prepared and tested according to SRPS U.M1.016 for frost resistance M-200.

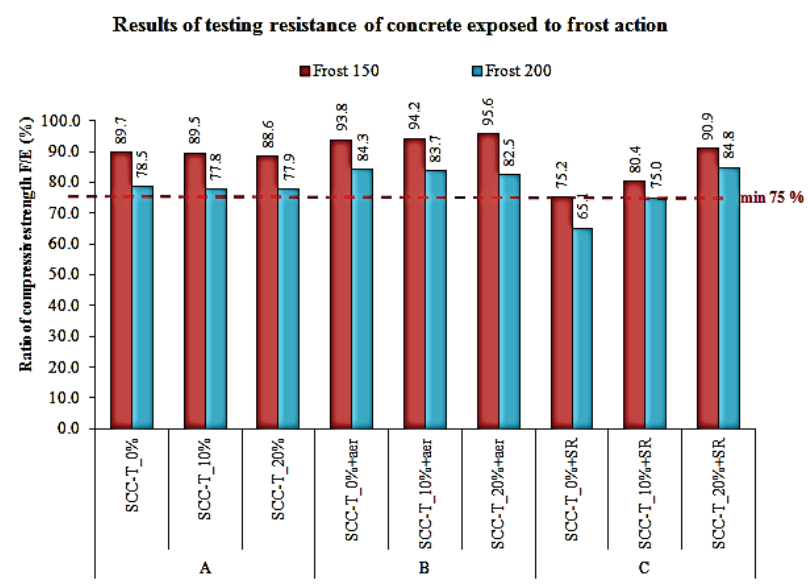

Figure 7 Ratio of compressive strength frozen/referent specimens (\%)

After preparation, the samples were exposed to cycles of freezing and thawing (a cycle consisting of $4 \mathrm{~h}$ of exposure of samples to the temperature of $-20^{\circ} \mathrm{C}$ and $4 \mathrm{~h}$ of thawing in water at $+20{ }^{\circ} \mathrm{C}$ ). Appropriate referent specimens were cured under normal laboratory conditions at a temperature of $+20 \pm 2{ }^{\circ} \mathrm{C}$.
The criterion for determining the frost resistance was that the compressive strength of frozen samples must be at least $75 \%$ of the strength the samples of equivalent age that were not frosted have. The results are given in Figure 7.

\subsubsection{Determination of air void characteristics in hardened concrete}

For obtaining concrete resistant to frost and to frost with de-icing salts, additional porosity is introduced into the structure of mortar using the aeration process, by applying air-entraining admixture there by forming air bubbles ranging in size from 0,01 to $0,3 \mathrm{~mm}$. Their optimal percentage is $4 \div 6 \%$, but it is also necessary that they are evenly distributed. If the requirements of the regulations are satisfied in terms of component materials for concrete, the quantity of cement, water-cement ratio and strength class, spacing factor (average maximum distance from any point in the cement stone to the edge of the nearest bubble) plays the key role in increasing the frost resistance of concrete. For values $<0,20 \mathrm{~mm}$ it is considered that concrete is resistant to frost with de-icing salts according to SRPS U.M1.206 [9].

For the same samples, tested by destructive method, was cut off one side of the cube $h=10 \mathrm{~mm}$ to determine the spacing factor of micropores in concrete with Rapid Air 457. Test results are shown in Tab. 6 and Fig. 8.

Table 6 Test results obtained by device Rapid Air 457

\begin{tabular}{|c|c|c|c|c|c|c|c|c|c|}
\hline \multirow[b]{2}{*}{$\begin{array}{l}\text { Results of testing } \\
\text { by Rapid Air } 457\end{array}$} & \multicolumn{9}{|c|}{ Concrete series } \\
\hline & $\begin{array}{l}\text { SCC- } \\
\text { T_0\% }\end{array}$ & $\begin{array}{l}\text { SCC- } \\
\text { T } 10 \%\end{array}$ & $\begin{array}{l}\text { SCC- } \\
\text { T_20\% }\end{array}$ & $\begin{array}{c}\text { SCC- } \\
\text { T } 0 \%+\text { aer }\end{array}$ & $\begin{array}{l}\text { SCC- } \\
\text { T } 10 \%+\text { aer }\end{array}$ & $\begin{array}{c}\text { SCC- } \\
\text { T } 20 \%+\text { aer }\end{array}$ & $\begin{array}{c}\text { SCC- } \\
\text { T } 0 \%+\mathrm{SR}\end{array}$ & $\begin{array}{c}\text { SCC- } \\
\text { T_10\%+SR }\end{array}$ & $\begin{array}{c}\text { SCC- } \\
\text { T } 20 \%+\mathrm{SR}\end{array}$ \\
\hline $\begin{array}{c}\text { Spacing factor } \\
(\mathrm{mm})\end{array}$ & 0,243 & 0,231 & 0,250 & 0,195 & 0,148 & 0,135 & 0,259 & 0,179 & 0,174 \\
\hline
\end{tabular}

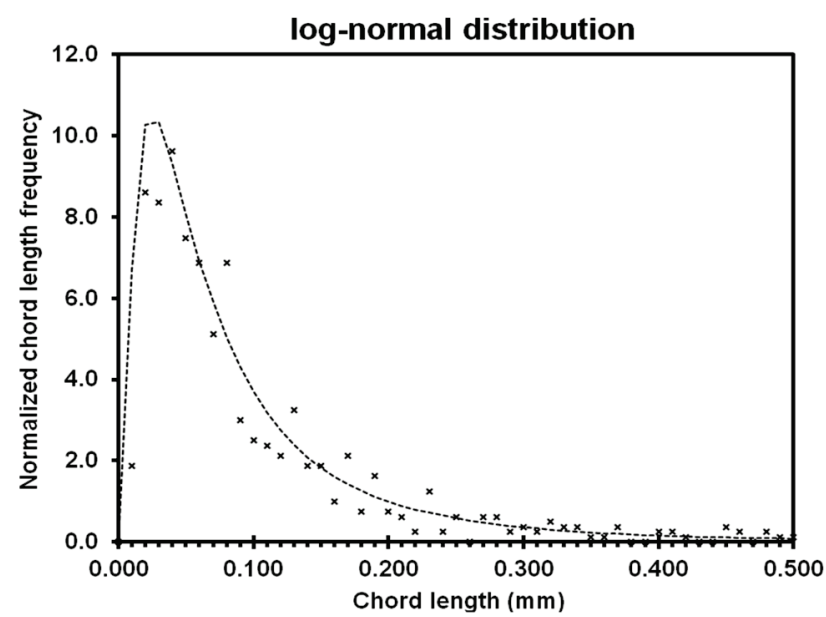

Figure 8 Air void distribution for concrete SCC-T_0\%+aer

\section{Conclusions}

The results of pozzolanic activity were extremely low, which has confirmed the results of the calculation of reactive $\mathrm{SiO}_{2}$ content. Thus it was concluded that this material is not suitable as a material for cement replacement in concrete and mortar or as a pozzolanic cement additive. Further investigations are focused on the possibility of tailings substituting a part of aggregate in the preparation of mortar and concrete.
By using tailings to replace a part of fine aggregate SCC was obtained. Concrete with $10 \%$ and $20 \%$ addition of tailings achieved higher strengths when compared to the reference concrete at 28 days of age.

The investigation of SCC with partial replacement of fine fractions of 10 and $20 \%$ with tailings showed good results for frost resistance. Concrete that in itself had air entraining agent showed better test results. All concrete has met the minimum ratio of frost/referent compressive strength of $75 \%$ for class M-200 (resistant after 200 cycles freezing and thawing), except concrete with CEM III without tailings which satisfied requirements for class M-150.

Checking concrete under the Rapid Air 457 microscope provided the indicators that are consistent with the results of the destructive tests. Spacing factor was less than $0,2 \mathrm{~mm}$ for concrete which is resistant to freezing and thawing with de-icing salts.

The results presented in this paper show that it is possible to use tailings from the $\mathrm{Pb}$ and $\mathrm{Zn}$ mine in selfcompacting concrete and that the best effect is achieved by replacing the fine fractions of aggregate with $10 \%$ of the tailings.

For the concrete to be self-compacting, a large amount of fine particles is necessary. That amount was obtained from adding fillers. Further research is needed to 
check the tailings in the SCC as a partial replacement of fine aggregate, but without the use of fillers.

\section{Acknowledgments}

The work reported in this paper is a part of the investigation within the research project TR 36017 "Utilization of by-products and recycled waste materials in concrete composites in the scope of sustainable construction development in Serbia: investigation and environmental assessment of possible applications" and Slovenia-Serbia cooperation project "Application of industrial waste materials in concrete production", supported by the Ministry of Education, Science and Technology, Republic of Serbia. This support is gratefully acknowledged.

\section{References}

[1] Thomas, B. S.; Damare, A.; Gupta, R. C. Strength and durability characteristics of copper tailing concrete. // Construction and Building Materials. 48, (2013), pp. 894900. DOI: 10.1016/j.conbuildmat.2013.07.075

[2] Onuaguluchi, O.; Eren, O. Recycling of copper tailings as an additive in cement mortars. // Construction and Building Materials. 37, (2012), pp. 723.727.

[3] Choi, Y. W.; Kim, Y. J.; Choi, O.; Lee, K. M.; Lachemi, M. Utilization of tailings from tungsten mine waste as a substitution material for cement. // Construction and Building Materials. 23, (2009), pp. 2481-2486. DOl: 10.1016/j.conbuildmat.2009.02.006

[4] González-Corrochano, B.; Alonso-Azcárate, J.; Rodas, M. Effect of prefiring and firing dwell times on the properties of artificial lightweight aggregates. // Construction and Building Materials. 53, (2014), pp. 91-101. DOl: 10.1016/j.conbuildmat.2013.11.099

[5] González-Corrochano, B.; Alonso-Azcárate, J.; Rodas, M. Effect of thermal treatment on the retention of chemical elements in the structure of lightweight aggregates manufactured from contaminated mine soil and fly ash. // Construction and Building Materials. 35, (2012), pp. 497507. DOI: 10.1016/j.conbuildmat.2012.04.061

[6] Argane, R.; Benzaazoua, M.; Bouamrane, A.; Hakkou, R. Cement hydration and durability of low sulfide tailingsbased renders: A case study in Moroccan constructions. // Minerals Engineering. 76, (2015), pp. 97-108. DOl: 10.1016/j.mineng.2014.10.022

[7] Argane, R.; Benzaazoua, M.; Hakkou, R.; Bouamrane, A. A comparative study on the practical use of low sulfide basemetal tailings as aggregates for rendering and masonry mortars. // Journal of Cleaner Production. 112, (2016), pp. 914-925. DOI: 10.1016/j.jclepro.2015.06.004

[8] SRPS EN 206-9, Concrete: Additional Rules for Selfcompacting Concrete (SCC), 2010

[9] SRPS U.M1.206 - Concrete - Specification, performance, production and conformity - Rules for the implementation of SRPS EN 206-1, 2013

\section{Authors' addresses}

Ksenija Janković, Ph.D.,BSCE, senior research associate IMS Institute

Bul. vojvode Mišića 43, 11000 Belgrade, Serbia E-mail: ksenija.jankovic@institutims.rs

Nenad Šušić, Ph.D., BSCE, principal research fellow IMS Institute

Bul. vojvode Mišića 43, 11000 Belgrade, Serbia E-mail: nenad.susic@institutims.rs

Marko Stojanović, M.Sc., BSCE, research assistant IMS Institute

Bul. vojvode Mišića 43, 11000 Belgrade, Serbia E-mail: marko.stojanovic@institutims.rs

Dragan Bojović, M.Sc., BSCE, research assistant IMS Institute

Bul. vojvode Mišića 43, 11000 Belgrade, Serbia E-mail: dragan.bojovic@institutims.rs

Ljiljana Lončar, BSCE

IMS Institute

Bul. vojvode Mišića 43, 11000 Belgrade, Serbia E-mail: 1jiljana.loncar@institutims.rs 